\title{
APLIKASI TEKNOLOGI TEPAT GUNA THERESER MULTIGUNA UNTUK PETANI PADI DAERAH PERBATASAN DHARMASRAYA
}

\author{
Junil Adri ${ }^{1)}$, Refdinal ${ }^{2}$ \\ ${ }^{1}$ Fakultas Teknik, Universitas Negeri Padang \\ email: juniladri@ft.unp.ac.id \\ ${ }^{2}$ Fakultas Teknik, Universitas Negeri Padang \\ email: refdinal@ft.unp.ac.id
}

\begin{abstract}
Abstrak
Kendala atau permasalahan yang ada pada petani saat ini adalah masalah pasca panen. Permasalahan terletak pada mesin perontok gabah. Mesin perontok gabah yang dimiliki bertipe Dragon dan mesin ini masih kurang efektif karena banyak gabah yang terbuang. Tenaga yang dibutuhkan juga cukup banyak dalam mengumpulkan gabah yang telah di rontokkan. Sehingga komplikasi permasalahan ini selain jumlah mesin belum mencukupi kebutuhan, mesin yang ada pun kurang efektif dan efisien dalam membantu proses panen para petani. Sehingga berdampak pada turunnya kualitas dan kuantitas padi yang akan di dapatkan petani. Dari fenomena ini TIM pengabdian menawarkan solusi membuat mesin theresher multiguna. Haparan mesin thereser ini mampu bekerja lebih efektif dari mesin yang sebelumnya. Metode penerapan ipteks yang dilakukan pada kegiatan ini adalah dengan memberikan teori pengantar, demonstrasi, dan praktek. Teori pengantar bersifat aplikatif yakni pengenalan alat, bagaimana cara penggunaannya, fungsinya serta aplikasi pemakaian di lapangan. Hasi dari pengabdian ini berupa mesin thereser multiguna menggunakan motor penggerak 9 HP untuk mencapai kinerja maksimal dan mesin thereser multiguna dilengkapi dengan lorong penghembus guna memisahkan padi berisi dan padi kosong.
\end{abstract}

Kata kunci: aplikasi tepat guna, mesin thereser multiguna, pengabdian masyarakat, petani daerah perbatasan, dan kabupaten dharmasraya.

\section{PENDAHULUAN}

Beras merupakan bahan makanan pokok bagi sebagian besar penduduk Indonesia. Erwidodo (2006) mengutip data Susenas yang menunjukkan bahwa $98 \%$ penduduk Indonesia mengkonsumsi beras sebagai bahan makanan pokoknya. Sementara itu kebijakan pemerintah dalam perberasan mempunyai pengaruh yang sangat besar pada stabilitas ekonomi dan politik di Indonesia. Beras merupakan salah satu unsur yang sangat penting yang menentukan tingkat inflasi pada gilirannya tingkat stabilitas perekonomian normal. Karena itu pemerintah Indonesia berusaha agar persediaan beras nasional selalu memadai dan harganya terkendali. Guna mencapai sasaran tersebut pemerintah menetapkan berbagai kebijakan perberasan dalam berbagai bidang seperti kebijakan harga. Pengadaan sarana dan prasarana produksi, investasi dalam bidang adalah dengan mengimport beras dari negara tetangga. Nawacita pemerintahan penelitian dan penyuluhan di sektor pertanian serta rekayasa kelembagaan.

Peranan sektor pertanian yang tangguh seperti yang diharapkan dalam proses pembangunan, sedikitnya mencakup empat aspek: Pertama, kemampuannya dalam menyediakan pangan bagi rakyat. Kedua, memberikan kesempatan kerja bagi masyarakat. Ketiga, menghemat dan menghimpun devisa dan yang keempat, sebagai dasar yang memberikan dukungan terhadap sektor yang lain (Laksono, 2008). Menurut teori ekonomi neoklasik perilaku konsumen, setiap konsumen individu dihadapkan dengan harga pasar ditentukan dari berbagai komoditas, dengan konsumen yang hanya memiliki penghasilan uang dikenal dan tetap (Odusina, 2008).

Permasalahan pada tahun 2017 Indonesia kekurangan ketersediaan stok pangan. Solusi yang diberikan pemerintah 
Jokowi-JK belum terealisasi pada sektor pertanian. Penurunan ketersediaan pangan menjadi nilai ukur hal tersebut. Krisis ini disebabkan oleh banyak faktor, diantaranya tidak sebandingnya laju pertambahan penduduk dibandingkan dengan ketersediaan lahan pertanian, adanya pertukaran fungsi lahan dan perubahan bentuk petanian pangan menjadi pertanian perkebunan, dan lainlain. Salah satu daerah yang masih memiliki banyak lahan pertanian padi nya adalah kabupaten Dharmasraya.

Dharmasraya adalah sebuah kabupaten yang terletak di perbatasan provinsi Sumatera Barat yang berjaran 240 KM dari pusat ibu kota Provinsi. Kabupaten Dharmasraya merupakan daerah agronmi pertanian. Kawasan tang datar dan subur menjadikan daerah ini memiliki potensi besar dalam perkembangan bidang pertanian. Saat ini ada tiga sektor bidang pertanian yang sedang berkembang di kabupaten Dharmasraya, diantaranya kelapa sawit, karet dan padi. Untuk petanian padi, kebutuhan air sudah dipenuhi oleh irigasi, karena hampir seluruh kawasan Dharmasraya sudah teraliri irigasi. Sehingga setiap tahunnya masyarakat dapat melakukan cocok tanam padi sebanyak tiga kali dalam setahun.

Dari survey kelapangan, kendala atau permasalahan yang ada pada petani saat ini adalah masalah pasca panen. Keterangan dari kelompok tani Rawang Bintungan dan kelompok tani Kayu Aro, para petani perontok gabah. Selain itu harga sewa mesin perontok gabah cendrung mahal. Hal ini terkadang menjadi keresahan bagi petani dalam proses panen. Memang sudah ada beberapa mesin perontok milik perorangan, namun jumlah itu belum cukup untuk memenuhi kebutuhan para petani, terkhusus kelompok tani Rawang Bintungan dan kelompok tani Kayu Aro.

Mesin perontok gabah miliki perorangan yang digunakan bertipe Dragon yang ada itu masih kurang efektif,

masih banyak gabah yang terbuang. Tenaga yang dibutuhkan juga cukup banyak dalam mengumpulkan gabah yang telah di rontokkan. Sehingga komplikasi permasalahan ini selain jumlah mesin belum mencukupi kebutuhan, mesin yang ada pun kurang efektif dan efisien dalam membantu proses panen para petani.

Solusi yang mungkin ditawarkan melalui pengabdian kepada masyarakat ini adalah dibuatnya mesin thereser multiguna yang efektif secara kontruksi dan efisien secara operasionalnya bagi para petani. Rancangan akan lebih sederhana, ringan segingga mudah untuk dipindahpindahkan. Harapannya melalui pengabdian ini masyarakat petani di Kabupaten Dharmasraya khususnya petani dalam lingkup kelompok tani Rawang Bintungan dan Kelompok Tani Kayu Aro dapat lebih mudah menangani padi saat pasca panen.

Kegiatan pengabdian kepada masyarakat yang dilaksanakan di Kenagarian Koto Padang ini bertujuan untuk meringankan beban kerja yang dihadapi petani pada saat pasca panen. Permasalahan yang dihadapi petani pada saat pasca panen akan berdampak pada turunnya kualitas dan kuantitas padi yang akan di dapatkan petani. Dari fenomena ini TIM pengabdian menawarkan solusi membuat mesin thresher multiguna. Haparan mesin thereser ini mampu bekerja lebih efektif dari mesin yang sebelumnya ada

Manfaat kegiatan pengabdian kepada masyarakat ini yaitu akan meringankan kerja petani dan lebih mengenalkan kepada petani tentang teknologi tepat guna terutama pada kelompok tani Kayu Aro dan Rawang Bintungan.

Pasca panen adalah serangkaian kegiatan yang meliputi pemanenan, perontokkan, pengeringan, pengangkutan, penggilingan, penyimpanan, dan pemasaran. Penanganan pasca panen yang baik dapat menekan hasil kehilangan panen yang cukup signifikan. Tujuan penanganan pasca panen yaitu menekan 
kehilangan hasil, meningkatkan kualitas beras, memperluas kesempatan kerja, serta meningkatkan nilai tambah. Masalah pokok dalam kegiatan pasca panen adalah menekan kehilangan hasil, hal ini karena kurangnya kesadaran petani untuk melakukan kegiatan pasca panen yang

baik. Kegiatan tersebut meliputi perontokkan, pengeringan, pengangkutan hasil panen, penyimpanan, penggilingan, pengemasan, serta penjualan atau pemasaran (Herawati, 2008).

Selain selama kualitas bibit dan budi daya, penanganan pasca-panen juga berpengaruh besar dalam menentukan kualitas beras. Penanganan pasca-panen bertujuan untuk menekan kehilangan hasil, meningkatkan kualitas, meningkatkan daya simpan dan daya guna komoditas pertanian, meningkatkan nilai tambah serta memperluas kesempatan kerja. Tahapan proses penanganan pasca-panen padi yang dilakukan oleh petani dimulai dengan penentuan umur panen hingga pengemasan untuk dijual. Berikut adalah tahapan yang harus dilakukan petani pada saat pascapanen padi sebelum padi siap disimpan atau digiling untuk dijadikan beras.

Ini merupakan tahapan awal dari kegiatan pascapanen. Jika penumpukan dan pengumpulan tidak dilakukan dengan benar akan berdampak pada kehilangan hasil yang tinggi. Agar tidak menimbulkan kehilangan hasil yang tinggi, penumpukan dan pengumpulan padi dianjurkan menggunakan alas. Dengan begini, kehilangan hasil dapat ditekan hingga 0,94-2,36\%.

Perontokan ini dapat dilakukan dengan perontok bermesin ataupun dengan tenaga manusia. Bila menggunakan mesin,

perontokan dilakukan dengan menyentuhkan malai padi ke gerigi alat yang berputar. Sementara perontokan dengan tenaga manusia dilakukan dengan cara memukul-mukul batang padi, malai padi pun dapat diinjak-injak agar gabah rontok. Untuk mengantisipasi agar gabah tidak terbuang saat perontokan maka tempat perontokan harus diberi alas dari anyaman bambu atau lembaran plastik tebal (terpal).

Kelompok tani adalah sekumpulan petani baik dewasa, pria, dan wanita maupun tua muda yang tidak terikat secara formal dalam suatu wilayah kelompok atas dasar keserasian dan kebutuhan bersama serta berada di lingkungan pengaruh dan pimpinan seorang kontak tani. Kelompok tani adalah kelembagaan tani yang langsung mengorganisir petani untuk mengembangkan usahataninya. Kelompok tani umumnya terbentuk pada lingkup desa. Setiap desa umumnya terdiri dari beberapa kelompok tani. Gabungan dari kelompok tani dalam satu desa disebut gapoktan. Kelompok tani merupakan wadah pembinaan petani yang membangun pertanian Indonesia. Kelompok tani pada dasarnya mampu memiliki posisi tawar yang cukup baik apabila mereka mampu meningkatkan kualitas output yang dihasilkan (Sucihatiningsih dan Waridin, 2010).

Kelompok tani memiliki fungsi yang penting untuk menjalankan konsep hak petani kedalam kebijakan, strategi dan program yang layak dalam satu kesatuan utuh. Kelompok tani dapat menjadi tempat belajar, berdiskusi, mencari informasi, bertemu, dan berbagi pengalaman antar anggota kelompok. Anggota kelompok

seharusnya saling membantu dan bergotong royong dalam kehidupan seharihari dengan begitu secara tidak langsung kelompok telah membantu anggota dalam meningkatkan pendapatan (Ramadoan et al., 2013).

Kemajuan teknologi yang berkembang dalam perontokan padi dianjurkan menggunakan pedal thresher dan power thresher. Perontokan padi model pedal threser hanya membutuhkan satu orang setiap alatnya dengan mengandalkan tenaga manusia sebagai mesin penggerak. Teknologi power thresher menggunakan alat yang lebih canggih jika dibandingkan dengan cara pedal threser, sehingga kapasitasnya pun lebih besar yaitu sebesar 500-1200 kg/jam sehingga pekerjaan cepat 
selesai. Kehilangan hasilnya pun sangat rendah, gabah yang dihasilkan bersih dan bermutu tinggi. Kekurangan cara ini, alat yang digunakan berat dan harganya sangat mahal sehingga sering tidak terjangkau oleh petani.

Power thresher merupakan teknologi di bidang pertanian yang berguna untuk merontokan padi yang sudah dipanen sebelumnya (Kementerian Pertanian, 2015). Banyak petani yang menggunakan teknologi power thresher karena dengan menggunakan teknologi tersebut, petani dapat menghemat tenaga kerja yang dikeluarkan, hasil rontokan gabah lebih bagus, biaya yang dikeluarkan lebih sedikit, mempercepat proses pascapanen dan dapat menekan tingkat kehilangan hasil dalam perontokan. Pada tahap perontokan, kehilangan hasil dapat mencapai $5 \%$ (Kementerian Pertanian, 2015). Kehilangan hasil yang terjadi pada saat perontokan dengan menggunakan alat "gebot", pedal thresher, dan power thresher secara berturut-turut setara dengan $266.24 \mathrm{~kg} / \mathrm{ha}, 258.95 \mathrm{~kg} / \mathrm{ha}$, dan $59.75 \mathrm{~kg} / \mathrm{ha}$ (Hasbullah \& Indayani, 2009).

Kegunaan mesin power thresher selain untuk merontokan padi juga dapat digunakan untuk merontokan biji-bijian seperti jagung dan kedelai. Perbandingan cara perontokan gabah antara gebot, pedal thresher dan power thresher menunjukan bahwa dengan menggunakan mesin power thresher persentase gabah tidak rontok sangat rendah jika dibandingkan dengan yang lain. Rata-rata hanya 0,49 gabah yang tidak rontok, sedangkan denggan menggunakan cara gebot dan pedal thresher masing-masing secara berurutan sebesar $1,76 \%$ dan 3,20\% (Hasbullah \& Indayani, 2009).

Penggunaan mesin power thresher sangat sederhana, letakan mesin di tempat yang rata dan dekat dengan tumpukantumpukan padi yang telah dipanen, setelah posisi mesin sudah tepat kemudian hidupkan mesin dan didiamkan sejenak. Setelah beberapa saat masukan sedikit demi sedeikit padi ke mesin, lakukan dengan perlahan agar tidak terjadi overload. Apabila sudah mendekati overload, kurangi sedikit pemasukan bahan kedalam mesin agar mesin tetap lancar beroperasi dan setelah selesai segera dibersihkan dari kotoran-kotoran yang tersisa (Kementerian Pertanian, 2015)

\section{METODE PENELITIAN}

Penerapan Ipteks yang dilakukan adalah dengan memberikan demontrasi dan aplikasi langsung di lapangan tentang bagaimana melakukan proses perontokan dengan thereser multiguna, petani juga akan diberi penjelasan standar keselatan yang harus diketahui petani dalam mengoperasikan mesin thereser multiguna. Material mesin thereser multiguna yang ditawarkan dalam kegiatan pengabdian dipililh material yang berbahan ringan. Pemilihan material ini dimaksudkan untuk bobot mesin lebih ringan sehingga mudah dipindah-pindah. Motor penggerak yang digunakan adalah motor bensin 9 HP. Mekanisme pemisah padi berisi dan padi kosong dirancang menggunakan lorong dan di hembus dengan kipas yang dipasang pada motor penggerak.

Metode penerapan ipteks yang dilakukan pada kegiatan ini adalah dengan memberikan teori pengantar, demonstrasi, dan praktek. Teori pengantar bersifat aplikatif yakni pengenalan alat, bagaimana cara penggunaannya, fungsinya serta aplikasi pemakaian di lapangan.

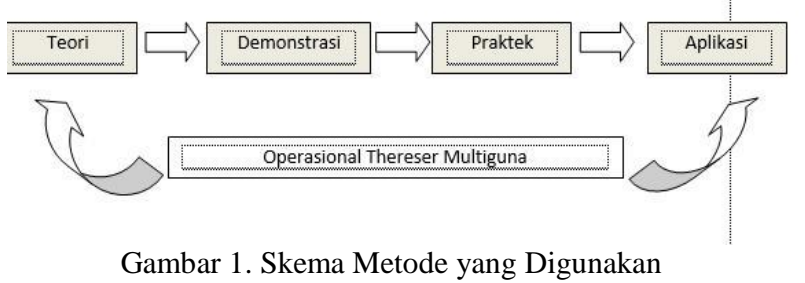

Metode ini disesuaikan dengan skematik kerangka pemecahan masalah. Permasalahan muncul dikarenakan berbagai macam faktor, khalayak sasarannya adalah kelompok tani. Sesuai dengan tujuan yang akan dicapai pada kegiatan ini adalah menghasilkan para 
petani yang trampil dan tanggap akan teknologi tepat guna sekaligus mempunyai motivasi maka, metode yang diterapkan adalah dengan memberikan pelatihan langsung pada para petani untuk mengoperasikan mesin thereser multiguna.

\section{HASIL DAN PEMBAHASAN}

\section{A. Proses Pembuatan dan Rencana Pelaksanaan}

1. Proses Pembuatan

a. Design Mesin Thereser Multiguna Proses pembuatan dilaksanakan di workshop Fabrikasi Jurusan Teknik Mesin Fakutas Teknik Universitas Negeri Padang. Pelaksanaan kegiatan dimulai dengan membuat gambar rancangan mesin. Rancangan ini bertujuan membuat mesin yang lebih efektif dibandingkan dengan mesin yang ada di pasaran. Dalam rangcangan TIM pengabdian menambahkan lorong penghembusan yang menjadikan mesin ini mampu memisahkan padi berisi dan padi hampa yang melewati lorong tersebut.

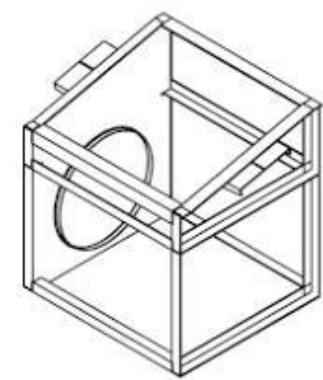

Gambar 2. Rancangan Rangka
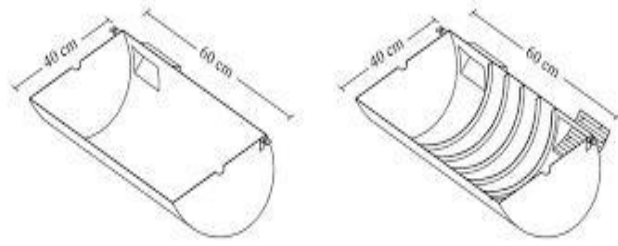

Gambar 3. Rancangan Tutup Bagian Atas

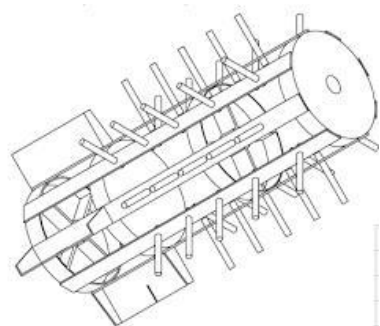

Gambar 4. Rancangan Roda Perontok

\section{b. Pembuatan Rangka}

Setelah gambar rancangan selesai maka proses pembuatan dilakukan. Proses pembuatan rangka dimulai dengan proses marking pada besi yang akan digunakan. Dalam pembuatan rangka mesin thereser multiguna ini digunakan mesi siku 40 x 40 mm. Rangka pada mesin ini dibuat ukuaran 900 x $600 \mathrm{~mm}$. pada rangka juga dilakukan proses pengeboran yang akan digunakan untuk dudukan bearing. Berikut bentuk rangka yang di buat.

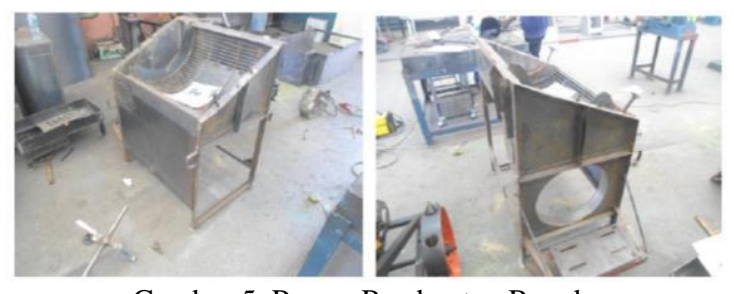

Gambar 5. Proses Pembuatan Rangka

c. Proses Pembuatan Roda Perontok

Roda perontok dibuat dengan ukuran diameter $20 \mathrm{~cm}$ dan panjang $90 \mathrm{~cm}$. Dasar roda perontok dibuat dengan besi plat 4 $\mathrm{mm}$ yang dibulatkan. Untuk skor penyangga dan dudukan baut perontok di buat dengan besi strip 1 inchi. Baut yang digunakan adalah baut M 10 dengan jumlah 90 buah. Pada roda perontok juga dilengkapi dengan kipas pembuang jerami. Berikut adalah bentuk roda perontok yang dibuat.

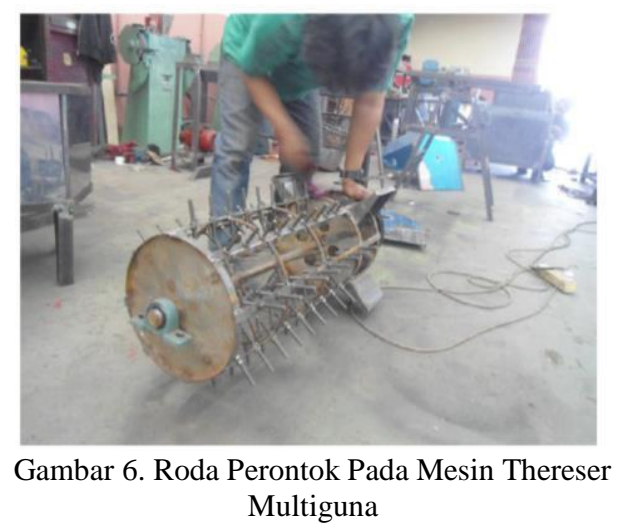

d. Proses Pembuatan Komponen Bagian Atas Thereser

Komponen bagian atas thereser multiguna ini berupa tutup mesin yang dibuat dari besi plat $1 \mathrm{~mm}$. tutup mesin ini 
dibuat dengan bentuk setengah lingkaran. Pada bagian dalam dibuatkan sirip alur untuk mengarahkan jerami yang telah dirontok pada kipas pembuangan. Pada pinggiran komponen atas diperkuat dengan pemasangan besi strip $20 \mathrm{~mm}$. Untuk menghubungkan tutup bagian atas ini dengan bodi thereser digunakan engsel peluru dan di lengkapi dengan tuas pengunci sehingga praktis untuk dibuka dan ditutup. Berikut adalah bentuk bagian atas thereser yang dibuat.

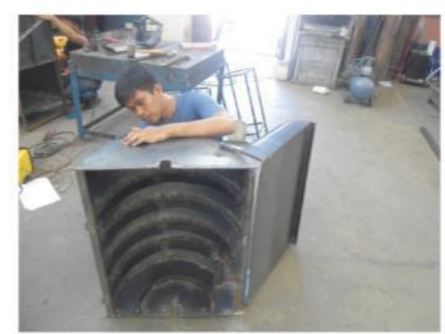

Gambar 7. Komponen Bagian Atas Thereser Multiguna

e. Pembuatan Lorong Peniup

Lorong peniup ini merupakan lorong tempat jatuhnya butiran padi. Pada motor penggerak selain ditempatkan pully juga ditempatkan kipas penghembus. Yang mana kipas tersebut akan menghembuskan angin menuju lorong penghembus dan akan menjadikan padi yang jatuh kelorong terhembus. Kuatnya hembusan angina menjadi factor pemisah antara padi berisi dan padi hampa. Padi hampa akan tertiup lebih jauh dibandingkan dengan padi berisi. Lorong ini di las langsung pada rangka dari thereser. Berikut bentuk lorong yang dibuat.

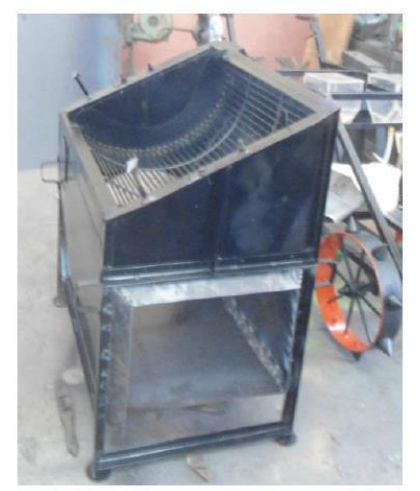

Gambar 8. Lorong Penghembus Pada Mesin Thereser

\section{f. Proses Finising}

Proses finising ini adalah proses penggerindaan semua komponen dan proses pengecatan. Warna yang digunakan adalah warna oranye dan hitam. Berikut adalah foto dari proses fisinising

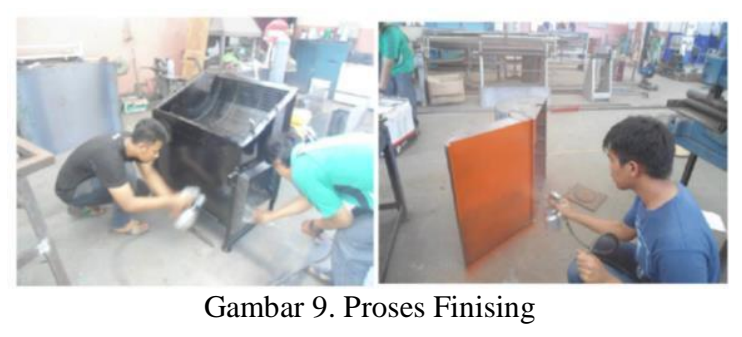

g. Proses Assembly

Proses assembly adalah proses penggabungan semua komponen dan pemasangan mesin pada bodi thereser multiguna. Berikut adalah foto dari proses assembly mesin thereser multiguna.

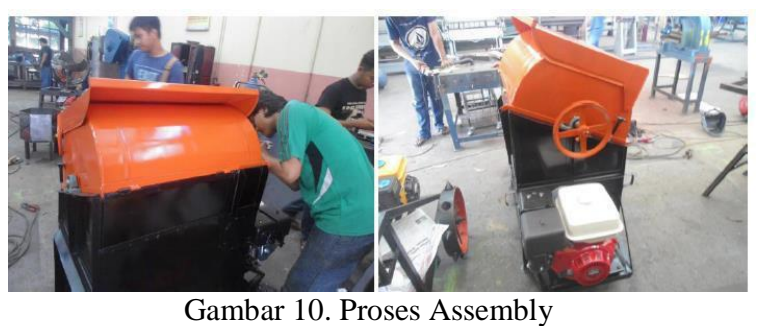

\section{Hasil Pelaksanaan}

Hingga laporan kemajuan ini dibuat, kegiatan yang dilakukan baru sebatas pembuatan mesin thereser multiguna. Secara fisik, TIM pengabdian menilai bahwa mesih ini sudah beroperasi sebagaimana mestinya. Untuk mengetahui ferforma mesin secara real tentunya TIM pengabdian akan mengantarkan dan menyerahkan mesin ini kepada khalayak sasaran yaitu kelompok tani Rawang Bintungan dan Kelompok Tani Kayu Aro yang berada di Kenagarian Koto Padang kabupaten Dharmasraya.

\section{KESIMPULAN}

A. Kesimpulan

1. Mesin thereser multiguna menggunakan motor penggerak 9 HP untuk mencapai kinerja maksimal. 
2. Mesin thereser multiguna dilengkapi dengan lorong penghembus guna memisahkan padi berisi dan padi kosong.

\section{B. Saran}

Kenagarian Koto Padang Kecamatan Koto Baru berada di daerah perbatasan antara Suamtera Barat dan Jambi. Nagari ini jauh dari pusat Ibu Kota Provinsi. Dari data pusat statistic tingkat pendidikan di negeri ini baru berumur 8 tahun yang mana artinya rata-rata masyarakat di kabupaten Dharmasraya tingkat pendidikannya hanya sampai pada kelas 8 atau kelas 2 SMP. Fenomena ini tentu menjadikan teknologi yang dimiliki masyarakat masih jauh dari harapan. TIM pengabdian mengharapkan kepada pihak LP2M dan dosen-dosen Universitas Negeri Padang untuk lebih banyak melakukan kegiatan Penelitian atau Pengabdian kepada masyarakat di daerah perbatasan guna meningkatkan kesejahteraan baik secara ekonomi ataupun pendidikan masyarakat Dharmasraya.

\section{DAFTAR PUSTAKA}

K, Pertanian. 2015. Basis Data EksporImpor Komoditi Pertanian. Diperoleh dari website Kementerian Pertanian Republik Indonesia:http://www.pertanian. go.id (diakses pada tanggal 14 April 2017).

Erwidodo. 2006. Analisis Hubungan Proporsi Pengeluaran dan Konsumsi Pangan dengan Ketahanan Pangan Rumah Tangga Petani Padi di Kabupaten Klaten. [Jurnal]. SEPA:vol.7 No.2 februari 2011. hal 110-118

Herawati. 2008. Analisis Permintaan Beras di Sumatera Utara. QE Journal. Vol.01-No.03-38.

Laksono. 2008. Analisis ketersediaan pangan wilayah berdasarkan neraca bahan makanan (NBM) dan pola pangan harapan (tingkat pertama). Kerjasama bagian Bina Ketahanan Pangan

Biro Bina Produksi Setda Provinsi Jawa Barat dengan tim Bagian Kebijakan Pangan Departemen Gizi Masyarakat Fakultas Ekologi Manusia Institut Pertanian Bogor.

Odusina, O.A. 2008. Urban Rice Demand Analysis: A Case Study of Ijebu Ode Township. Middle-East Journal of Scientific Research 3 (2): 62-66, 2008.

Odusina. 2008. Kedaulatan Lahan \& Pangan Mimpi atau Nyata. Jakarta: Direktorat Jenderal Prasarana dan Sarana Pertanian Kementerian Pertanian. 148 hal

Purnamaningsih, R dan Ika, M. 2005. Seleksi in vitro Tanaman Padi untuk Sifat Ketahanan Terhadap Aluminium. Jurnal Bioteknologi Pertanian.10: 61-69.

Ramadoan et al. 2013. Permintaan Beras di Provinsi Jambi (Penerapan Partial Adjustment Model). Jurnal Perspektif Pembiayaan dan Pembangunan Daerah. Vol. 1 No. 1, Juli 2013.

Rouw Aser. 2008. Analisis dampak kerahaman curah hujan terhadap kinerja produksi padi sawah (studi kasus di Kabupaten Merauke, Papua. Jurnal Pengkajian dan Pengembangan Teknologi Pertanian 11 (2) : 145154.

Sucihatiningsih Dian Wisika dan Waridin. 2010. Model Penguatan Kapasitas Kelembagaan Penyuluh Pertanian dalam Meningkatkan Kinerja Usahatani Melalui Transaction Cost. Studi Empiris di Provinsi Jawa Tengah. Jurnal Ekonomi. 